\title{
Lessons to Be Learned from Groundwater Trading in Australia and the United States
}

\author{
Sarah Ann Wheeler, Karina Schoengold, and Henning Bjornlund
}

\begin{abstract}
This chapter provides an overview of the issues and challenges facing policy makers intending to establish groundwater markets. It studies in detail two developed countries that have introduced groundwater trading and have some experience in its implementation-Australia and the United States of Americaand draws out lessons from these countries that need to be considered for the development of groundwater markets around the world. The key lessons that this chapter stresses are: the importance of establishing institutions and regulations; investing in high quality economic and scientific research; that opportunities arise from crises; and that social concerns are not always the most important considerations to be aware of for efficient and effective groundwater markets.
\end{abstract}

\subsection{Groundwater Global Over Extraction and Shortage}

Globally, groundwater extraction is the outcome of decisions by organisations and individuals; there is little control or planning involved with its management. Groundwater withdrawals supply a large percentage of the world's population. It accounts for about $50 \%$ of global drinking water and $43 \%$ of global irrigation (van der Gun 2012). As detailed in Chap. 2, its overuse is associated with several

\author{
S.A. Wheeler $(\square)$ \\ Global Food Studies, University of Adelaide, Adelaide, SA, Australia \\ e-mail: sarah.wheeler@adelaide.edu.au \\ K. Schoengold \\ Agricultural Economics and School of Natural Resources, University of Nebraska, Lincoln, NE, \\ USA \\ H. Bjornlund \\ School of Commerce, University of South Australia, Adelaide, SA 5000, Australia
}


negative externalities including: water drawdown and groundwater depletion; land subsidence; loss of biodiversity; reduced dilution and assimilation of contaminants; increased salinity; pollution; and seawater intrusion into coastal aquifers (Moreaux and Reynaud 2004; Goesch et al. 2007). In some of the world's most important food producing regions, such as Punjabi in India, Northern Plains in China and the Ogallala aquifer in the United States, over extraction has now reached levels where it is apparent that it will not be possible in the longer term to support irrigation at current levels (Shah 2009). It is thus a major threat to food security.

The extraction of groundwater during the twentieth century was mainly for irrigation. Given the increasing impact of climate change on surface water availability, it is likely the pressure on groundwater will increase in the future (van der Gun 2012). The Brundtland report in 1987 increased the awareness that there had been over-allocation of water reserves and that groundwater was being drained more quickly than it could be replenished. This led to the emergence of the concept of 'safe yields', which set upper limits on the available water for use without depleting storage. However, this did not protect the interests of other users of water, notably the environment (Richardson et al. 2011).

\subsubsection{Groundwater Features}

Aquifers are recharged by rainwater, snow melt and returns from irrigated agriculture. Sometimes water moves considerable distances underground. Aquifers can be depleted if more water is extracted than the annual recharge. For several decades, aquifers in arid and semi-arid regions have been stressed with a growing gap between extraction and recharge. This has direct economic impacts because of increased pumping costs for consumptive users and water degradation and ecosystem damage (Esteban and Albiac 2012). Stocks of groundwater in aquifers are often larger than surface water stocks. This makes them important buffers during prolonged dry spells where, with reduced surface water availability and increased demand, groundwater use typically increases during droughts (van der Gun 2012; Goesch et al. 2007).

Groundwater management is more challenging than surface water management because it is less visible and recharge is more difficult to measure than stream inflows. Also, the hydraulic interconnectedness between different aquifers and between aquifers and surface water is still not fully understood in many regions. Groundwater is much more poorly monitored relative to surface water. It is only in recent years that authorities in many countries have started to require meters to be installed and monitored on bores (i.e., wells). For example, in Australia, by 2007 only 20-40 \% of major groundwater users were monitored (Goesch et al. 2007).

Another feature of groundwater is its 'shared water' component; that is, the interconnectedness of aquifers and streams. Shared water is that component that feeds into a stream or river from an aquifer (gaining stream) or that discharges into an aquifer from a river (losing stream). In some areas, a single river can gain and lose water (Goesch et al. 2007). Some ecosystems, such as wetlands, small streams, rivers, and lakes, are fed by aquifers (Esteban and Albiac 2012). 
Managing the quality of groundwater also poses a challenge, as problems such as salinity are common (Chap. 15). The susceptibility to quality pollution depends on the properties of the soil, climatic conditions, location of aquifers and factors such as rainfall frequency. The type of cropping, as well as fertilizer and pesticide application, also influence the risk of pollution. Short duration crops lead to greater levels of leaching (Arthukorala and Wilson 2012). Further, certain irrigation practices, failure to dispose of waste water properly and land clearing can all decrease groundwater quality (NWC 2012).

To understand groundwater use, a model of groundwater flow systems is required, including its sources and the spatial nature of natural and induced or imposed recharge and discharge. Quantifying recharge from all sources is difficult, as is determining the amount of water extracted. Thus where overuse is suspected, regular measurement is essential (Athukorala and Wilson 2012).

\subsection{Groundwater Policy Frameworks}

In the 1990s there was a shift in thinking about water within the international community. It was generally recognised that the possibilities of increasing water supplies had ended and there should be a shift in focus to managing water demand and reallocation. The global document Agenda 21, emerging from the Rio Convention in 1992, reflected this thinking and its main elements for dealing with water shortage included the notions that:

- users should pay the full cost of water;

- water markets should be established;

- the community should be involved in the decision making process

- water use should be more efficient; and

- the environment must be recognized as a legitimate stakeholder (Sitarz 1993).

Strategies must be found to more purposefully allocate water in ways that respond to competing demands, promote sustainability, prevent environmental damage and generate economic efficiency. In general, existing diversions can be reallocated or reduced through an administrative reallocation of water rights, information approaches or market-oriented policy approaches (Bennett 2008). Government managed 'command and control' approaches can be unpopular, while market based instruments are frequently regarded as politically neutral, and as an efficient means of managing water under conditions of scarcity (Skurray et al. 2013). However, many countries are heavily influenced by political influences which means second-best policy approaches are often chosen when first-best policies are available (for example, see Crase (2011) for a discussion of the Australian water situation). Markets, by contrast, allow for voluntary action informed by price signals and market forces. 


\subsubsection{Water Market Conditions}

Before the establishment of water markets in any area, four broad elements are needed to drive efficient use and outcomes. These are:

- A fixed limit to resource availability (set consumptive pool) that is ideally: (i) credible and based on accurate science; (ii) monitored and enforced; and (iii) consistent with sustainable levels of extraction;

- Users are provided with secure property rights in the form of an access entitlement to a share of that consumptive pool;

- These shares, and the water allocated to them each season, are tradeable under low transaction costs and entry/exit barrier conditions, such that ownership, control and use can change over time; and

- Prices for these shares and allocations that take into account externality costs to third-parties are established in a market that uses the value placed on water use by a large pool of well-informed buyers and sellers (NWC 2011; Bjornlund et al. 2013; Loch et al. 2013).

For groundwater markets in particular, there need to be well-defined rights with limited groundwater use allocations and monitoring of groundwater extraction by all users. These rights and allocation levels need to be based on a good understanding of the hydrogeology of a groundwater area, groundwater mobility and its sustainable yield, along with knowledge of dependent ecosystems and the way the aquifer responds to extraction. However, caution needs to be taken that property rights to water can be reduced when necessary for environmental or climate purposes, or due to uncertainty about watershed hydrology. It has been proposed that sustainable yield be managed by defining lower and upper bounds for water table levels and monitor them (Anderson and Snyder 1997). Entrenching property rights in water can be problematic. Firstly, there is the issue of dozer and sleeper rights (e.g. unused or unutilized water rights). For example, establishing water markets in Australia activated many unused licences, and reduced the water left in the river. Secondly, enshrining property rights holds dangers if there is incomplete knowledge of riverine ecosystems and future environmental needs for water (Crase et al. 2004; Young 2014).

\subsubsection{Difficulties in Establishing Groundwater Markets}

Bauer (1997) argues that establishing markets in water resources is difficult. Water markets are not natural or self-maintaining. Further, the institutional frameworks, the political and economic conditions, as well as geographic context are important influences on market function. Regulation is necessary to prevent third party effects and externalities. Despite the need to clearly define property rights, some aspects of water resources are inherently public goods and represent collective interests. Government oversight is also very important for markets to work effectively, 
particularly in relation to assessing trade applications, monitoring and reporting on the state of ground and surface water resources and market performance, revising trading rules as appropriate and ensuring water management plans are adequate (GHD et al. 2011). However, markets are embedded in institutions which can either facilitate or impede their optimal functioning. High transaction costs can be a significant disincentive to trade and they are likely to be particularly relevant when establishing new markets since they involve a change from historical systems of water management. Such costs can arise from the transaction itself or they can be generated by the institutional factors that are necessary in enabling trade (Skurray et al. 2013; Garrick et al. 2009).

\subsubsection{Property Right Issues}

The characteristics of groundwater and surface water and their interaction differ in ways that lead to various challenges in defining property rights to each type of resource. These differences also affect the complexities involved in developing water markets.

With surface water, movement across boundaries can be difficult to control. Moreover simultaneous and sequential users of water make exclusion difficult and create numerous interdependencies. Thus, multiple parties can be affected by surface water trading. Also, in some countries, individuals do not own water; it is owned by the state and held in trust for individual citizens, creating a legal impediment to developing property rights. There is also a chronological hierarchy in claims to water (similar to the framework of high, medium and low security water rights used in countries such as Australia) which may not be correlated to the value of its use (Brewer et al. 2008).

Surface water markets also depend on conveyance opportunities and the absence of canals, or rivers, to move water can decrease arbitrage opportunities. Markets tend to be local because of regulation between different states and the cost of transporting water over long distances (Brewer et al. 2008). It is essential that market boundaries are clearly defined; this relates to physical boundaries as well as volumetric ones. Finally, Crase et al. (2004) suggest that efficiency improvements may not return water to the environment unless there are institutional mechanisms to direct saved water to environmental flows.

In contrast, groundwater aquifers have many of the characteristics of a common property resource where the location of the user is important. Early work on groundwater management (e.g., Gisser and Sanchez 1980; Gisser 1983) modelled groundwater as a spatially homogeneous common property resource (i.e., the "bathtub" model), where one individual's groundwater use immediately affected all other users equally. More recent work (e.g., Brozović et al. 2010) shows that while groundwater aquifers have some characteristics of a common property resource, the impact of one individual's use on other users varies over space and time from one aquifer to another, depending on hydrological characteristics. This distinction is important for the appropriate definition of property rights and the region where trading is permitted. It is important for policymakers to first set the 
total level of groundwater use rights for an aquifer to a sustainable level, then the important task is the distribution of those rights over the aquifer.

Given the inherent and manifold difficulties in specifying property rights in groundwater, greater specification of rights and their conditions seems a tempting option. However, greater specification decreases the ease of transferability of rights. The greater the degree of specification, the thinner the market and the less benefits it will generate. The alternative to extensive specification of property rights is introducing other measures to prevent environmental and other third party effects (Skurray et al. 2013).

Aquifers can vary markedly in terms of their hydrogeological properties, with consequent variation in the ease of extracting water, the capacity for recharge, the difficulty of specifying property rights and the external costs associated with accessing groundwater from them. Therefore, it may be difficult to expect management regimes to be applied to a number of different aquifers. Furthermore, management regimes are often embedded in administrative jurisdictions that do not necessarily align with the boundaries of aquifers. Decision making must therefore address and integrate interconnected natural systems. A further element of flexibility relates to the temporal variation in aquifer 'behaviour'. Responsiveness to changing conditions should override a reliance on rigidly applied and upheld regulations (Skurray et al. 2013).

The physical differences between surface water and groundwater systems also affect the ease of monitoring water use. Well-defined property rights that are quantifiable and can be monitored are essential for a water market. Surface water systems are more likely to have (but note this is far from certain) a well-developed infrastructure of rivers and canals that make quantifying water use relatively straightforward. Water flows can be measured at each point of diversion to determine water use by individuals or communities. By contrast, groundwater is generally extracted through a network of individual wells, which are interconnected horizontally depending on geology. Quantifying water use can require installing flow meters at each well and collecting information on actual water use. Quantifying use also can be estimated by a range of various models. While the monitoring technology is readily available to collect this information for groundwater use, the cost of doing so is higher for groundwater than for surface water systems. The higher monitoring cost is one reason that many areas have been slower to limit groundwater than surface water. In addition, the interconnectedness of groundwater and surface water adds to the complexity of establishing property rights. Property rights to surface water and groundwater need to be coordinated to incorporate the physical connection between the two resources.

\subsubsection{Externalities}

Due to the common pool ownership of aquifers, and the unique physical properties of aquifers, externalities are easily created. Because of the spatially-dynamic nature of groundwater flow, the extent of various externalities depends on the quantity, location and time of extraction and the strategic behaviour of users. In a competitive and unregulated setting, the temporal and spatial profile of external effects results in 
inefficient pricing and misallocation; users take too much, too quickly and from what may be considered the wrong locations (e.g. closer to surface water rivers). Individual users of groundwater have, in the absence of regulation or other incentives, little reason to consider the increased pumping costs for other users as a result of the extraction they undertake (Katic and Grafton 2012). Nor is there much incentive to consider future costs associated with reduced stock. Finally, they have little reason to consider the impact of their activities on surface water, where groundwater extractions can decrease the amount of surface water available (Goesch et al. 2007). Regulation is needed. Groundwater is not used optimally by individuals who do not internalize the part of the extraction costs and environmental externalities in their pumping decisions. Extraction by one user will deplete the water supply and, because users believe competitors will not conserve water, there is little incentive to protect the storage. This is a significant reason for market failure and highlights the need for institutional arrangements. A key issue is therefore whether markets are capable of achieving balanced inter-temporal allocation of resources (Esteban and Albiac 2012).

\subsection{Actual Groundwater Trade}

Notwithstanding the complexity of the physical influences on groundwater, its use is also inextricably linked with socio-economic, legal, institutional and political systems. There are several drivers of groundwater access and use: other water sources; demographic and socio-economic factors; science and technological innovation; policies, laws and financial conditions; climate variability and market changes (changed demand, changed renewal, availability of other sources) (van der Gun 2012).

Surface water markets around the world occur mainly in semiarid areas and include: United States (mostly in the western states), Chile (Limarí River Valley), Australia (Murray-Darling Basin), Spain, Canada (South Saskatchewan River Basin), South Africa, China, Brazil, Mexico and Tanzania (Loch et al. 2013; Wheeler et al. 2014). All water markets can be hampered by political, technical, social and administrative factors. However, markets in groundwater face some particular challenges, including the three dimensional nature of aquifers, boundary uncertainties, water quality variation and local drawdown impacts. Groundwater markets are less common than surface water markets but some exist in Australia (Skurray et al. 2013; Skurray and Pannell 2010), China (Zhang et al. 2008; Wang et al. 2007), Oman (Zekri and Al-Marshudi 2008; Al-Marshudi 2007), the Indian Subcontinent (Meinzen-Dick 1998; Shah 1993; Easter et al. 1998) and the United States (Colby 2000; Colby and Bush 1987; Anderson and Snyder 1997; Griffin 1998).

The specific details of markets can vary by location. For example, in China, Oman, and India groundwater trading typically occurs when water is sold and transported to be used on non-adjacent land. In Australia and the United States groundwater trading generally involves selling the right to pump water from a 
shared aquifer. However, some of the major groundwater transfers in the US have taken place by purchasing water farms and pumping the water to distant cities, especially in Arizona, with detrimental impact on exporting regions This distant pumping has also taken place in California and Texas (Colby and Bush 1987; Anderson and Snyder 1997). The Omani and Indian/Pakistan groundwater markets provide some interesting insights on groundwater opportunities and problems. A brief discussion is provided in Box 20.1.

\section{Box 20.1: Examples of Groundwater Markets in Developing Countries India and Pakistan}

Informal groundwater markets have developed in India and Pakistan where irrigation water is supplied from deep tubewells which are costly to install (Meinzen-Dick 1998; Shah 1993; Easter et al. 1998). This excludes small farmers from accessing water. However, many of them can buy water from large farmers with excess capacity. There are various arrangements for payment: (i) the buyer pays an agreed amount or works for the larger farm in exchange for water; (ii) two-way share farming: one party supplies the water, the other the land and labour and all share net profits; (iii) three-way share farming: one party supplies the water, another the land and the third the labour and all share net profits.

These groundwater markets increase availability and reliability of water supplies; but the ability to sell water, combined with subsidized electricity prices, encourages over-extraction of groundwater. This results in increased pumping costs, elimination of use of shallow wells, and increased saline aquifers.

Oman

A unique groundwater market has developed in Oman within the falaj irrigation systems (Zekri and Al-Marshudi 2008; Al-Marshudi 2007; Bjornlund and Bjornlund 2010). There are 1,000 year old underground water mobilization systems tapping water from the top of mountain aquifers and transporting it by gravity-driven tunnels and canals to villages and fields (with domestic use given first priority). The system can only tap the aquifer's overflow, and access is granted in flow time only; hence access is correspondingly reduced in times of shortage. In most systems, the majority of water is controlled by the village community and semi-public charity organizations, such as the mosques. Many farmers are dependent on buying water access either on a weekly or annual basis. The proceeds from the weekly auctions are used to pay for the administration and maintenance of the falaj system, while the water controlled by semi-public organizations is sold annually and the proceeds go towards community activities. Many of the systems are currently under threat due to external encroachment on this communal resource (e.g. farmers have sunk tube wells into aquifers supplying the falaj systems).

The remainder of this paper studies in detail two of the most advanced countries in the world in terms of groundwater trading: Australia and the United States. 


\subsubsection{Australia}

In Australia, groundwater has typically been: (i) unmetered; (ii) provided free or at low prices; and (iii) 'managed' by management plans, which have not properly considered the connectivity between surface and groundwater (NWC 2012). Groundwater use almost doubled between 1983/4 and 1996/7, but this average masks a tripling in the states of New South Wales, Victoria and Western Australia (where much of Perth's drinking water supply comes from groundwater). Under the National Water Initiative (NWI), Australian governments are committed to:

- improving knowledge of ground-surface water connectivity;

- returning all over-allocated systems to sustainable levels of extraction;

- improving understanding of what is a sustainable extraction rate; and

- improving understanding of the relationship between groundwater and groundwater dependent ecosystems (NWC 2008).

The National Groundwater Action Plan, arising from the 2007 evaluation of progress of the NWI, seeks to take the actions needed to achieve these outcomes. The National Water Commission (NWC) concluded in 2008 that ongoing use of groundwater for consumptive use from 'stressed' aquifers and connected systems is an 'unacceptable risk'. They then developed a set of principles to guide subsequent action (NWC 2008). Developing water markets in groundwater was one such consideration, though there were many considerations that needed addressing first (Goesch et al. 2007).

In 2004-05, ABS (2006) estimated that groundwater access entitlements accounted for 146,185 (or $65 \%$ ) of all water access entitlements and 6,998 GL of water allocated in Australia. As at June 2012, NWC (2013) suggested there were 81,719 groundwater entitlements issued, covering about 6,600 GLs (the majority are in New South Wales, followed by Western Australia, Victoria, Queensland and South Australia) (Table 20.1).

Table 20.1 Groundwater entitlements on issue at 30 June 2012

\begin{tabular}{l|c|c}
\hline Jurisdiction & Number & Volume (GL) \\
\hline New South Wales (NSW) & 47,835 & 2,056 \\
\hline Queensland (Qld) & 8,153 & 1,008 \\
\hline Victoria (Vic) & 8,956 & 950 \\
\hline Western Australia (WA) & 11,400 & 1,713 \\
\hline South Australia (SA) & 4,911 & 620 \\
\hline Tasmania (Tas) & 0 & 0 \\
\hline Northern Territory (NT) & 232 & 125 \\
\hline Australian Capital Territory (ACT) & 262 & 76 \\
\hline Total & $\mathbf{8 1 , 7 1 9}$ & $\mathbf{6 , 5 9 6}$
\end{tabular}

Source: NWC (2013) 
Table 20.2 Groundwater entitlement and allocation trading in 2011-12

\begin{tabular}{|c|c|c|c|c|c|c|c|c|}
\hline & Qld & $N S W$ & Vic & $S A$ & $W A$ & $N T$ & Tas & $A C T$ \\
\hline Entitlement (no) & 0 & 208 & 304 & 202 & 68 & 0 & 0 & 0 \\
\hline $\begin{array}{l}\text { Entitlement volume } \\
\text { (ML) }\end{array}$ & 0 & 84,377 & 35,325 & 15,725 & 11,004 & 0 & 0 & 0 \\
\hline Allocation (no) & 62 & 134 & 97 & 41 & 29 & 0 & 0 & 0 \\
\hline $\begin{array}{l}\text { Allocation volume } \\
\text { (ML) }\end{array}$ & 3,688 & 26,972 & 7,524 & 2,147 & 4,255 & 0 & 0 & 0 \\
\hline
\end{tabular}

Source: NWC (2013)

Groundwater entitlement trading made up only about $12 \%$ of total trade in Australia in 2011-12 (NWC 2013). The number and volume of entitlement and allocation trade is shown in Table 20.2.

\subsubsection{Murray-Darling Basin (MDB) Groundwater Trade}

In the MDB, most surface and groundwaters are hydraulically linked; meaning that overuse of surface water will deplete aquifers, while increased groundwater extraction will adversely affect the supply of surface water. Groundwater comprises about $15 \%$ of irrigation water in the MDB, but this can increase to over $70 \%$ in some catchments in extended dry conditions (Richardson et al. 2011).

As of 2012, annual groundwater extractions from the MDB were 1,744 GL per annum. However, the MDB Plan allows for an increase up to a total of 4,340 GLs annually. Of this increase, $760 \mathrm{GL}$ is due to be extracted from aquifers that need to have extractions reduced or capped. In some areas of the MDB, extraction exceeds recharge capacity with poor long term outcomes for groundwater levels (Wentworth Group of Concerned Scientists 2012).

Policies and guidelines for sustainable groundwater extraction are currently being developed. In the past, an extraction limit was defined as part of a technical process and then announced via a water plan. This has worked reasonably well, but has led to some tensions. These tensions were mainly about the over-extraction of groundwater because of a development imperative, unchecked by knowledge of the ecological needs served by, and dependent on, groundwater (Richardson et al. 2011).

In some areas people use groundwater in dry periods to augment the supplies they receive from surface water (NWC 2011). Groundwater trade is permitted in New South Wales, South Australia, Victoria, the Northern Territory and Western Australia. However only a small amount of trade has occurred (e.g. Tables 20.2, 20.3, and 20.4).

Table 20.4 indicates that groundwater and unregulated trade only made up $2 \%$ of total MDB water allocation trade in 2011-12, while Table 20.3 shows it made up $14 \%$ of total MDB water entitlement trade. Overall, groundwater trading within the southern MDB increased significantly during the 2000s from 2-5\% of total groundwater use to 10-20\% (NWC 2010).

One of the first active groundwater markets was in the Northern Adelaide Plains, where urban encroachments into market gardening areas left many ground water 
Table 20.3 Australian water trade volumes

\begin{tabular}{l|c}
\hline (GL) in 2011-12 & Water entitlements \\
\hline MDB regulated & 1,065 \\
\hline MDB unregulated and groundwater & 153 \\
\hline Other water systems & 218 \\
\hline Australia total & 1,437 \\
\hline
\end{tabular}

Source: Adapted from data in NWC (2013)

Table 20.4 Water allocation trading volumes (GL), Australia, 2007-08 to 2011-12

\begin{tabular}{l|c|c|c|c|c}
\hline & $2007-08$ & $2008-09$ & $2009-10$ & $2010-11$ & $2011-12$ \\
\hline MDB Regulated & 1,376 & 1,663 & 2,118 & 3,340 & 4,127 \\
\hline $\begin{array}{l}\text { MDB Unregulated and } \\
\text { groundwater }\end{array}$ & 17 & 290 & 183 & 76 & 89 \\
\hline MDB total & 1,393 & 1,953 & 2,301 & 3,417 & 4,216 \\
\hline Other water systems & 201 & 205 & 194 & 77 & 81 \\
\hline Total Australia & 1,594 & 2,158 & 2,495 & 3,493 & 4,297 \\
\hline
\end{tabular}

Source: NWC (2013)

licenses unused. Trading was allowed to enable this water to move to remaining market gardeners. However, this caused water extraction to concentrate withdrawal in the most productive region and after only 4 years of trading a large cone of depression developed in this area. This resulted in the introduction of zones and trade limitation between some zones (Boyd and Brumley 2004).

Access to groundwater for irrigation is governed by entitlement and is usually separate from land and other property rights. Generally, each entitlement specifies the volume that irrigators can extract in a given year. But some entitlements specify daily pumping rates, while others specify additional volumes that can be withdrawn during droughts. Extraction in some areas is not sustainable. Sustainability is formulated by assessing extractions against sustainable yield. There is variation in the definition of sustainable yield. The National Groundwater Committee defines it as an extraction regime that allows acceptable levels of stress and protects economic, social and environmental values. This recognizes the trade-offs between competing uses (Goesch et al. 2007).

In the Namoi groundwater area in NSW, there is well developed trading in groundwater because of several initiatives. Firstly, over-allocation was addressed. This has allowed the setting of total extraction limits, with annual allocations announced at the beginning of the year. The key elements of successful trading activity in NSW are:

- high demand for groundwater;

- water sharing plans for aquifers based on sound scientific knowledge;

- access to perpetual licenses for users;

- transparent trading rules;

- efficient approval processes; and

- a system for metering and monitoring is in place (NWC 2011). 
Table 20.5 Groundwater and surface water allocation trade volumes, Namoi, 2006-07 to 2011-12 (ML)

\begin{tabular}{l|l|l|l|l|l|c}
\hline & $2006-07$ & $2007-08$ & $2008-09$ & $2009-10$ & $2010-11$ & $2011-12$ \\
\hline $\begin{array}{l}\text { Groundwater } \\
\text { allocation trade }\end{array}$ & 12,155 & 12,543 & 10,210 & 9,102 & 6,096 & 3,997 \\
\hline $\begin{array}{l}\text { Surface water } \\
\text { allocation trade }\end{array}$ & n.a. & 5,598 & 12,581 & 12,151 & 17,516 & 23,462 \\
\hline
\end{tabular}

Source: NWC (2013)

Table 20.5 illustrates the trade in groundwater and surface water allocations over the past 6 years. It highlights that groundwater trade was highest in the drought years of 2006-07 and 2007-08, while surface water trade is higher in years of higher rainfall (and higher water allocations).

Groundwater trade is comparatively much less developed in Victoria than in NSW. There seem to be a number of reasons for the under-developed trade in Victoria: (1) historical reliance on bulk water supply provider systems; (2) some groundwater regions are not fully allocated; (3) incomplete resource planning; and (4) underdeveloped market rules and institutions. In Victoria, just less than half of the groundwater management units are considered over-allocated, while $12 \%$ are considered less than $50 \%$ allocated. Within under-allocated units, new licenses are being issued and there is little incentive for trade. Furthermore, many 'sleeper' licenses have been issued. This would limit trade even in over-allocated areas, as many current licence holders already have the capacity to expand. However, there is compelling evidence that groundwater levels are declining in Victoria. Therefore, if increasing groundwater extraction continues, the predicted consequences of climate change eventuate and there is lack of recharge following drought, demand for trade should increase (NWC 2011).

A second barrier to trade in Victoria is lack of planning for management of groundwater resources. In areas designated as Water Supply Protection areas, trading in or out is not permitted until a management plan for the area has been developed. There have been delays in developing such plans because of lack of knowledge about aquifers and sustainable yields (again due to historical reliance on surface water systems and a lack of development on groundwater). In other areas, where trade in groundwater has been developed, or has the potential for such development, caps need to be set to ensure the volume that can be taken from a given groundwater management area in a given period is established. This requires defining the boundaries of the area so that they align with the hydrogeological boundaries of the aquifer and ensure that the boundaries of groundwater and surface water align. Without this consistent establishment of boundaries, it is difficult to properly manage the asset. There are a number of administrative barriers to groundwater trade in Victoria. These include unbundled licenses, licenses that are of short duration, lack of clarity about the basis for reducing seasonal allocations and complex and restrictive trading rules (NWC 2011). 


\subsubsection{Western Australia}

In 2011-12, there were over 11,000 ML of groundwater entitlements traded nationally and 4,255 ML of these groundwater allocations were traded in Western Australia (NWC 2013). In the Gnangara aquifer of Western Australia, the legal rights associated with a 10 year licence for a volume of groundwater are significantly attenuated because unused portions of water may be reclaimed by the relevant Minister. Rights can also be 'amended' by the Minister in order to protect third parties. In addition, the Government can amend a license if the reason for the use of water is not appropriate. Further, licences are time limited and do not represent an unconditionally owned asset. There are up to 80 conditions that relate to well depth, monitoring, infrastructure, reporting and time of use requirements (Skurray et al. 2013). Thus the property rights entailed by having a licence for Gnangara groundwater is administratively restricted, purpose limited, and time limited with conditional rights that are vulnerable to cancellation or amendment. While it might be argued that the Government control of certain aspects of water rights is a means to guarantee sustainable management of the resource, this has not proved to be the case. The current arrangements do not meet the NWI's guidelines for the creation of effective markets, despite the fact that the WA government is a signatory to the agreement. Transfers of water can only be made to a person who either owns, or occupies, the land on which the water will be used, or they must have written permission from the land owner to use the land for activities which are deemed appropriate under the conditions of the water licence. These significantly constrain the transferability of licences. The process for applying to transfer water is cumbersome, expensive and does not adequately maintain confidentiality. Moreover, even where transfers are approved by the Minister's office, they can be overridden by local regulations (Skurray et al. 2013).

\subsubsection{United States of America (US)}

Of critical importance in understanding the existence and potential for groundwater trading in the United States is the fact that water law is generally determined at the state level, as opposed to the federal level. There are some exceptions (e.g. the Endangered Species Act, which trumps state-level decisions when the habitat of an endangered species is at risk, or compacts that regulate interstate rivers such as the Colorado River). However, most groundwater law, including the rights structure, regulation, and the potential for groundwater trading varies by state and some states have further devolved groundwater management to regions, counties, or basins. For example, Texas groundwater law has historically given landowners an absolute right to use groundwater below the land, while Nebraska law is defined by "reasonable use" and "correlative" rights, which mean that groundwater users are expected to manage the resource jointly and restrictions affect all users equally.

The Edwards Aquifer in Texas has implemented regulation that restricts groundwater use and allows trading but the changes are not comprehensive across the state. In fact, in 2011 the Texas Legislature passed a bill that upheld the interpretation that 
landowners that are not in the Edwards Aquifer management area have "a vested ownership interest in and right to produce groundwater below the surface" (Eckhardt 2013). Kansas and Idaho use appropriative rights for groundwater so that groundwater is managed based on a "first in time, first in right" basis. Arizona regulates groundwater use based on a state law that requires an assured water supply for users (Megdal 2012), while California has little groundwater regulation at the state level, but allows local areas to develop more restrictions (Hanak 2003; Jacobs 2006).

States in the western parts of the US enshrined the environment's right to water under common law doctrines. However, given that these regulatory and administrative regimes are implemented by individual states, the result is very uneven in terms of the amount of reform achieved in each jurisdiction. Increasingly, private entities have engaged in buying or leasing high security water for the environment. As this activity has increased, so too has monitoring, scrutiny of transfer and enforcement of regulations (Garrick et al. 2009). While most of the purchases of water for environmental benefits have been for surface water, there are some cases where protecting environmental quality also helps groundwater resources. For example, protecting natural wetlands such as the playa system in the Southern High Plains has environmental benefits via the provision of important habitat and also helps recharge groundwater aquifers (Bolen et al. 1989).

Another important distinction between surface and groundwater rights is the incentive to use water. While the details vary by state, western states in the United States generally use the prior appropriation system for surface water. Under prior appropriation, failure to continue using water can result in rights being lost; this is a disincentive to using less water and those who save water often see it forfeited to others. This creates a situation in which there are rewards for using a lot of water to grow low value crops. California eliminated this disincentive with a regulation that allowed water saved to be sold, leased or transferred (Brewer et al. 2008). However, Garrick et al. (2009) suggests that the prior appropriation doctrine establishes an implicit cap on the amount of water available, which has been an incentive to the development of trading. In contrast, groundwater rights are more frequently determined on the basis of land ownership and are less likely to be subject to a "use it or lose it" clause. ${ }^{1}$ While this reduces the incentive for overuse, it fails to provide the implicit cap on available water.

Brewer et al. (2008) found in their review of surface water markets in the US that:

1. Agriculture is the origin for many of the transactions;

2. The annual flow of water traded and the amount of water committed for transfer show different patterns;

\footnotetext{
${ }^{1}$ This varies by state. In some states (e.g., Idaho, Montana) groundwater rights are based on prior appropriation and can be lost if unused. Other states (e.g., Arizona, California, Nebraska, and Texas) base rights on land ownership, making it difficult to lose a right if the land or pumping right is not sold.
} 
3. Number of trade transactions is increasing (mainly accounted for by agricultureto-urban trades);

4. Sales and multi-year leases are growing, while 1 year leases are not;

5. Arizona, Texas and California are among the top four states on any measure of trading;

6. Agriculture -to-urban trades account for most permanent trades on committed trade measures, while agriculture -to- agriculture trades account for most of the annual leases;

7. In comparing sales and leases across a number of US western states, prices varied more across states than across sectors and this differential reflects differences in demand and supply characteristics, transaction type, transaction costs and regulatory restrictions that prevent arbitrage across states. Sales are more common than leases of water (because of the greater security they provide) and this is reflected in increasing sales prices while those for leases have declined relatively; and

8. Finally, the price data reveal that urban users pay considerably more for water than agricultural users.

In contrast to surface water, in most places groundwater rights are not quantified; that is, there is no legal right for users to withdraw a specific amount of water. Thus there is a general right for all those who are located above the aquifer to pump from it. Basins where the rights to groundwater are specified are located primarily in urban areas. They usually charge pumping fees and manage recharge programs. The development of clearly defined and limited property rights to groundwater is a necessary condition for further development of groundwater trading.

\subsubsection{California}

While surface water markets were introduced in California in the late 1970s, the factors leading to their expansion in the 1990s were severe drought and government mandated environmental flows. Trade was initially spurred by dry years, but has persisted since the return of normal precipitation. In its early stages, most transfers were short term trades such as 1 year leases, but the percentage of longer term leases and permanent sales has increased. The proportion of sales has fluctuated but the trend in longer term leases is sustained. Since the late 1980s, the percentage of water bought or leased for cities and the environment has continued to increase relative to other uses (Hanak and Stryjewski 2012). However, there is some indication that overall trade has slowed in recent years (Hanak and Stryjewski 2012).

California provides an interesting example of water regulation and trading, with surface water laws clearly defined and a thriving surface water market, while groundwater regulation and associated trading is extremely limited and very little data exist. While groundwater management is improving in the state overall, it is still largely a voluntary system and groundwater regulations are primarily determined at a local level (Hanak and Stryjewski 2012). Groundwater is an important source of 'wet water' in California and groundwater transfers are subject to less 
oversight by the state than surface water since the state's water code does not cover groundwater (Hanak and Stryjewski 2012). Historically this meant that there was little regulation over groundwater use. This was highlighted after many surface water irrigators sold their water rights to the state in the drought of the late 1980s and early 1990s, only to respond by pumping groundwater as a substitute. This trend has not changed and the same pattern of irrigators substituting groundwater for limited surface water availability was also seen in the late 2000s (Famiglietti et al. 2011).

Groundwater banking has emerged as an important tool in California's water management, which involves the deliberate storage of surface water in aquifers during wet years (Hanak 2005). Since 2000, the state has been making active attempts to facilitate groundwater storage, which is part of the strategy to encourage conjunctive use of water as part of a diversification process (Hanak and Stryjewski 2012). The term "groundwater banking" is a misnomer: while a useful tool for managing water, in most parts of the state it is really a conjunctive management system although the details are case-specific. For example, some districts that use groundwater are purchasing surface water to augment local aquifers for local use. In other cases, municipalities are purchasing storage space in existing aquifers to store surface water. Groundwater banking describes the practice of storing surface water in natural or created aquifers during wet periods to save the water for dry periods. There are many benefits of groundwater banking for overall water management. It is a relatively cost-effective way to bolster water supplies especially in drought times. It also will help mitigate the loss of seasonal storage provided historically by the Sierra Nevada snowpack, which is expected because of climate change. Groundwater banking has become common in California (Hanak and Stryjewski 2012) and in Arizona (Megdal 2012) but typically does not actually involve the transfer of existing (i.e. natural) groundwater. However, any transfer of the banked water is often limited by local ordinances, limiting the benefits of water trading (Hanak and Stryjewski 2012).

There is a history of aquifers being drained, with adverse consequences for other users in California. This background helps to explain the development of local ordinances and the contemporary resistance to groundwater export from local communities. Many of the local ordinances restrict the export of groundwater. These ordinances are a significant deterrent to groundwater trade, which in many areas make groundwater transfers more difficult than surface water trades (Hanak 2003; Hanak and Stryjewski 2012). The efficiency of the approvals process for handling transfers is an important determinant of benefits of a market. Some counties place restrictions on groundwater exports and limitations on groundwater substitution transfers, while some aim to restrict groundwater banking with non-local parties. There are no state level 'no injury' groundwater protection statutes that can regulate groundwater (Hanak and Stryjewski 2012). In addition, there is local resistance to recent attempts by the state to collect information on groundwater use and groundwater levels. Without such information it is nearly impossible to develop a well-managed system of regulated groundwater rights that can facilitate groundwater trading. 
In summary, California provides an interesting example that shows strong differences in the approach to developing trade in groundwater versus surface water. However, despite the growing maturity of the surface water market, overall trade has been declining since 2003, despite some drought years since 2000. A number of factors appear to explain the reduction in surface water trade. New pumping restrictions since 2007 have impeded north to south and east to west transfers around the Delta. Aspects of the approval process have also impeded transfers (Hanak and Stryjewski 2012). At the same time, county ordinances have limited groundwater transfers. These transfers are subject to environmental strictures over and above those related to the 'no injury' to environmental flows. In both surface and groundwater, recent high commodity prices are associated with a reluctance to lease/sell water. Finally, the existence of different kinds of water rights with separate approval processes has dampened the market. Overall, developing a more robust groundwater market will require additional restrictions to limit groundwater use and well-defined property rights that are streamlined across different counties.

\subsubsection{Nebraska}

Nebraska has developed a system where groundwater law is developed at the state level but administered and managed at a local level. Groundwater law follows a system of correlative rights, which means that all groundwater users have equal rights to use the resource. The state is divided into 23 natural resource districts, or NRDs. The NRD boundaries are determined by watersheds and each NRD has responsibility for managing natural resources such as groundwater and soil. Each NRD has substantial autonomy in choosing how to interpret and apply any state groundwater laws, and they frequently impose additional regulations above state limits. In contrast, surface water use is managed by the state using a prior appropriation system.

Unlike states such as California that rely primarily on surface water, ${ }^{2}$ groundwater is the major source of water for Nebraska, providing approximately $85 \%$ of total water used (Kenny et al. 2009). Historically surface water and groundwater law in the state were separate. However, legal changes since the mid-1990s have provided legal recognition to the many hydraulically-connected surface and groundwater systems in the state. Much of the state's groundwater is connected to surface water basins, including the Platte River Basin and the Republican River Basin. A law passed in 2004 (Legislative Bill 962) requires many of the NRDs to cooperatively develop integrated management plans (IMPs) to specify how hydraulically connected groundwater and surface water will be jointly managed. One outcome of this change is that groundwater wells need to be certified, registered, and metered in much of the state. In addition to metering, many NRDs have set groundwater allocations for each well, establishing binding property rights for groundwater users. This combination of factors has allowed some of the NRDs to

\footnotetext{
${ }^{2}$ Approximately $80 \%$ of total water use in California is from surface water (Kenny et al 2009).
} 
permit groundwater trading to be used to improve the economic efficiency of groundwater use. However, variation exists between the approaches used by different NRDs:

Upper Republican Natural Resource District (URNRD): The URNRD was an early adopter of groundwater regulation. This primarily rural district, located in southwest Nebraska, initially required all irrigation wells to install flow meters in 1979. Use restrictions were also implemented in the same year, although the initial allocation levels were sufficiently high that users were not constrained. Allocations are determined for a multi-year period (typically for 5 years) and the allocations have gradually decreased. Initial water allocations were set at $5,610 \mathrm{~m}^{3} /$ year/hectare and current allocations are $3,315 \mathrm{~m}^{3} /$ year/hectare $(\mathrm{RRB}$ 2013). The expansion of acres is controlled, setting a cap on total water use. The allocation rights are allocated to each field based on the size of the field. Given the binding allocations and history of monitoring, the URNRD is well-suited for groundwater trading.

In the URNRD, an irrigator can transfer part of his/her water allocation to another irrigator if the water will be used within a confined geographical region (9,324 hectares). This constraint has advantages and disadvantages. The advantages are that it reduces regional economic impacts associated with the transfer of groundwater and can reduce the chance of cones of depression, where groundwater pumping is concentrated in a small area. Disadvantages accrue from limiting potential trading partners, reducing the potential economic benefits of trade. Relative to surface water, groundwater transfers have few technical impediments since the right to pump is transferred as opposed to the wet water. One impediment to groundwater transfers has been high transaction costs. There is no mechanism to help prospective buyers and sellers find trade partners. In addition to formally transferring allocation, the URNRD also allows an irrigator to combine the pumping rights to all of his/her land in a limited geographical area. This creates a defined set of fields (referred to as a "pool"). Total groundwater use is limited for the pool of fields, but the irrigator can choose how to distribute the total allocation between fields. This allows flexibility to move water from one field to another due to differences in soil type or crop choice. Many producers use pools to help manage their water allocation, and this suggests that reducing the transaction costs for formal trading would lead to more trades and greater economic benefits. In a recent analysis, Juchems (2013) found that indicators of profitability such as soil type, depth to groundwater, and pumping capacity are strong indicators of the direction of trade in both formal trades and within-pool transfers.

Lower Republican Natural Resource District (LRNRD): As with the URNRD, the LRNRD establishes multi-year groundwater allocations for irrigators. Due to changes in state law, the NRD began metering and limiting groundwater allocations in 2005. Unlike the URNRD, transfers of groundwater allocation are not permitted. Research suggests that modifying the rules to allow groundwater 
transfers would have economic benefits, and would allow the NRD to reduce overall groundwater use at a very low cost (Palazzo and Brozović 2014).

Central Platte Natural Resource District (CPNRD): The motivation for improved water management is different in the Platte River Basin than in the Republican River Basin. Both are interstate rivers and restrictions on hydraulically connected groundwater in the Republican River Basin have been necessary to provide enough water to Kansas (the downstream state). In contrast, restrictions on hydraulically connected groundwater in the Platte River Basin are designed to improve instream flow for endangered species. A series of interstate agreements and legislative changes between 1997 and 2006 led to the current restrictions and water management plan for the CPNRD.

The CPNRD has developed a number of tools to help groundwater users manage their water allocation. First, the CPNRD allows groundwater users to transfer (trade) the right to pump groundwater to another location. Transfers are permitted between the NRD and other NRDs as long as the transfer is approved (CPNRD 2012). The permitting process is designed to ensure that any transfer does not lead to additional depletion from the river. As seen in the URNRD, oneto-one transfers can have high transaction costs due to the difficulty of finding a trading partner. In addition to one-to-one transfers, the CPNRD has developed a water bank. To date most of the water bank activities have been permanent buyouts of irrigated land (both groundwater and surface water). However, the water bank has been designed to also permit some flexibility, with individual producers able to purchase water. While the program is still fairly new, the centralized system is expected to lead to lower transaction costs, more trades, and higher economic benefits from water use.

While each of the 23 NRDs differs in their approach to managing groundwater, these three examples highlight some of the groundwater trading activities that are already occurring. Jointly, these three case studies show evidence that there is demand for transfers and flexibility when it is permitted. The URNRD, which is fairly restrictive with formal transfers, had approximately 40 transfers during the 2005-2011 period (Juchems 2013). Transfers within a pool of fields are extremely common. The CPNRD has a more established system for transfers, and has approved many transfers. Thus, a key lesson from these experiences is that even with high transaction costs, there are economic benefits from groundwater transfers. While local control of groundwater resources is politically important across the state, the differences between districts illustrate how economic efficiency may be improved by relaxing constraints on groundwater trading and reducing transaction costs. Transferring the right to pump water, instead of moving water, reduces transportation costs but without oversight may lead to the problem of more intensive pumping in a small area, resulting in cones of depression.

\subsubsection{Edwards Aquifer (Texas)}

Texas has historically had a rule of capture for groundwater, where a landowner has the right to use groundwater below his or her land. While some of the state still 
operates under a 'rule of capture', the Edwards Aquifer in south-central Texas provides an example of groundwater management that includes some restrictions on use and permits groundwater trading. Motivated by threats to endangered species' habitat that depend on aquifer flow, the Texas legislature passed Senate Bill 1477 (SB 1477, known as the Edwards Aquifer Authority Act) in 1993 (Boadu et al. 2007). SB 1477 changed the water rights structure for groundwater users, created a permit system that gave a right to use a specified quantity of water, and created the Edwards Aquifer Authority (EAA). While some initial rights were allocated in the late 1990s, many water users felt the allocation was unjust, leading to extensive litigation (Colby 2000). A series of legal challenges delayed the assigning of most water rights until 2001 and 2002, when the legal authority of the EAA to restrict groundwater use was upheld by the Texas Supreme Court (Eckhardt 2013). Legal challenges have continued to lengthen the process of regulating the Edwards Aquifer, reducing the benefits of water permits and trading, and increasing stress on endangered species.

An analysis of the potential changes due to the regulation in SB 1477 finds that without regulation, low water flow will significantly affect habitat for endangered species (Gillig et al. 2004; Boadu et al. 2007). A recent analysis of proposed legislative changes has compared expected water flows and economic benefits with and without regulation and water markets. Results show that under regulation, flows are higher without water markets but that regulated water markets are necessary for habitat needs and that the economic loss due to regulation is reduced when trading is permitted (Gillig et al. 2004; Boadu et al. 2007). Results also show that unregulated groundwater use is expected to lead to insufficient water flow for endangered species.

The experience in the Edwards Aquifer shows that legal battles can reduce the benefits of water trading and regulation. In 2013, almost 20 years after the initial legislation to regulate groundwater and create tradable permits was passed, the expected benefits have still not been realized.

\subsection{Lessons Learned from Groundwater Trade in Australia and the US}

There are a number of lessons that can be learned from this review of groundwater trade in Australian and the US. They include:

1. Institutions matter: While there are physical limits on the operation of groundwater markets, in Australia it appears that institutional barriers are as significant an impediment to trade as hydrogeological factors. While groundwater trading is permitted everywhere, only in a few states is there much market activity and there are few trades relative to the number of entitlements held; this is largely because trades are concentrated in particular areas. There is no consistency about whether products are unbundled across states (NWC 2011). Variation in the 
rules established by Nebraska's different NRDs affects the frequency and feasibility of groundwater trading. The legal institutions involved in the management of the Edwards Aquifer in Texas have played a role in impeding the development of a viable water market.

2. Science matters: Before groundwater markets can be established, it is critical to understand and specify the boundaries of a groundwater management system. Groundwater systems should be based on physical aquifers, have clearly defined boundaries based on hydrogeological features. Interactions between surface water and groundwater need to be understood and incorporated, as well as the water quality of the system and the social and environmental externalities. Entitlement and extraction limits must be as accurate as possible, as should processes for changing long term entitlement and extraction limits, determining allocation limits and restricting extractions during periods of shortage (GHD et al. 2011).

3. A crisis can be an opportunity: Several examples of successful restructuring of water rights and the development of water trading are due to necessity. For example, a major impetus for the development and expansion of surface water markets in both Australia and California was a multi-year drought in the late 1980s and early 1990s (Bjornlund and McKay 2000; Hanak 2003). In California, where statewide groundwater legislation does not exist, courts have adjudicated radical changes to groundwater rights, management and trading in examples of severe stress, such as in the Tehachapi Basin and Mojace Basin north of Los Angeles (Anderson and Snyder 1997). Interstate legal conflicts in Nebraska led to legislative changes in the joint management of hydraulically connected surface and groundwater.

4. Economics matters: As well as the need to put proper institutions in place, there is a need for economics in groundwater management. There is a need to consider how many users there are in a management area, the value to be gained from trading groundwater, and the costs involved in establishing a market. A properly established market will grow in trade over time, and optimal water prices achieve efficient management by balancing benefits and costs across users and across time (Hansen 2012). Rural water users in the western USA have typically paid only for conveyancing and pumping cost of water, not its scarcity value. Markets will allow the movement of water to high value users.

5. Society's concerns do not always matter: Although policy needs to be concerned with social externalities from water markets, it is not something that should always be considered for designing efficient groundwater markets. This is where other policy needs to be put in place to address those rural social concerns; water markets should not be used as a second-best tool to address their problems. There have been a myriad of concerns about equity, low income impacts, rural community depopulation and the belief that water is a public good that have led commentators to imply that water should not be commodified (NWC 2012). However, setting water prices artificially low will result in inefficient pumping and consumption, and not allowing water markets to develop will deny rural users a valuable adaptation and risk measure (Hansen 2012). 
Finally, the most important point that needs elaborating upon is that flexibility matters. Flexibility in institutions, in policy, in scientific and social science research is needed to continually deal with changes in the environment, the climate and in rural conditions. There is an element of path dependence that has resulted in the way institutions in each country are established and policy prescriptions for a variety of environmental and water scarcity problems are made. In California, water marketing and groundwater banking are essential tools for helping water users to manage their scarce water resources more efficiently and sustainably. The continual development of such tools augments the ability to cope with future droughts (Hanak and Stryjewski 2012). In Australia, the decision to institute water markets, the setting of the initial Cap on water use and the inability to recognise that this would activate many unused water rights by such water owners selling their water, has led to the situation in the 2000s where governments are buying back billions of dollars of surface water entitlements in the MDB. By significantly increasing the demand for water entitlements (and paying what is perceived to be higher prices for water), this has also activated many farmers selling their surface water, and increasingly turning to their groundwater entitlements to support their farm production. It is predicted that this growth in groundwater use is unsustainable in the MDB. Such a situation highlights the importance of history, and of how various policy decisions play a part in creating further externalities down the line. It also highlights that policy needs to be flexible to deal with unintended externalities that have resulted from previous attempts to solve water issues.

Acknowledgements We are grateful for the research assistance of Jane Edwards in helping to prepare this manuscript. This research was supported by an ARC Discovery project DP140103946 and ARC Future Fellowship FT140100773.

Open Access This chapter is distributed under the terms of the Creative Commons AttributionNoncommercial 2.5 License (http://creativecommons.org/licenses/by-nc/2.5/) which permits any noncommercial use, distribution, and reproduction in any medium, provided the original author(s) and source are credited.

The images or other third party material in this chapter are included in the work's Creative Commons license, unless indicated otherwise in the credit line; if such material is not included in the work's Creative Commons license and the respective action is not permitted by statutory regulation, users will need to obtain permission from the license holder to duplicate, adapt or reproduce the material.

\section{References}

ABS (Australian Bureau of Statistics) (2006) Water account Australia: 2004-05. Australian Bureau of Statistics, Canberra

Al-Marshudi A (2007) The falaj irrigation system and water allocation markets in Northern Oman. Agric Water Manage 91:71-77 
Anderson T, Snyder P (1997) Water markets: priming the invisible pump. Cato Institute, Washington, DC

Athukorala W, Wilson C (2012) Groundwater overuse and farm-level technical inefficiency: evidence from Sri Lanka. Hydrogeol J 20:893-905

Bauer C (1997) Bringing water markets down to earth: the political economy of water rights in Chile, 1976-95. World Dev 25:639-656

Bennett J (2008) Defining and managing environmental flows: inputs from society. Econ Papers 27:167-183

Bjornlund V, Bjornlund H (2010) Sustainable irrigation: a historical perspective. In: Bjornlund H (ed) Incentives and instruments for sustainable irrigation. WIT Press, Southampton, pp p13-p24

Bjornlund H, McKay J (2000) Are water markets achieving a more sustainable water use? In: Proceedings from the Xth world water conference, Melbourne, 11-17 Mar

Bjornlund H, Wheeler S, Rossini P (2013) Water Markets and Their Environmental, Social and Economic Impact in Australia. In: Maestu J (ed) Water Trading and Global Water Scarcity: International Perspectives. RFF Press, Abingdon, pp 68-93

Boadu FO, McCarl B, Gillig D (2007) Empirical investigation of institutional change in groundwater management in Texas: the Edwards Aquifer case. An Nat Resour J 47:117-163

Bolen E, Smith M, Schramm H (1989) Playa lakes: prairie wetlands of the southern high plains. BioScience 39:615-623

Boyd T, Brumley J (2004) Optimising sustainable use of groundwater: a challenge for science and water markets. In: Paper presented at the 1st international conference on sustainability engineering and science, Auckland, 6-9 July 2004. Available at www.thesustainabilitysociety.org. nz. Accessed 4 July 2013

Brewer J, Glennon R, Ker A et al (2008) Water markets in the west: prices, trading and contractual forms. Econ Inq 46:91-112

Brozović N, Sunding D, Zilberman D (2010) On the spatial nature of the groundwater pumping externality. Res Energy Econ 32:154-164

Colby B (2000) Cap-and-trade policy challenges: a tale of three markets. Land Econ 4:638-658

Colby S, Bush D (1987) Water markets in theory and practice. Market transfer. Water values and public policy. Studies in water policy and management. Westview Press, Colorado

Crase L (2011) The fallout to the guide to the proposed basin plan. Aust J Publ Admin 70:84-93

Crase L, Pagan P, Dollery B (2004) Water markets as a vehicle for reforming water resource allocation in the Murray-Darling Basin. Water Resour Res 40:1-10

CPNRD (Central Platte Natural Resource District) (2012) Integrated management plan. http:// www.cpnrd.org/IMP\%20Final.pdf. Accessed 5 May 2013

Easter K, Dinar A, Rosengrant M (1998) The performance of water markets: transaction costs, interjurisdictional barriers and institutional options. In: Just R, Netanyahu S (eds) Conflict and cooperation on trans-boundary water resources. Kluwer, Boston, pp 299-313

Eckhardt G (2013) The Edwards Aquifer website. http://www.edwardsaquifer.net/rules.html. Accessed 3 July 2013

Esteban E, Albiac J (2012) The problem of sustainable groundwater management: the case of La Mancha aquifers, Spain. Hydrogeol J 20:851-863

Famiglietti J, Lo M, Ho S et al (2011) Satellites measure recent rates of groundwater depletion in California's Central Valley. Geophys Res Lett 38:L03403. doi:10.1029/2010GL046442

Garrick D, Siebentritt M, Alyward B et al (2009) Water markets and freshwater ecosystem services: policy reform and implementation in the Columbia and Murray-Darling Basins. Ecol Econ 69:366-379

GHD et al (2011) A framework for managing and developing groundwater trading. Waterlines report. National Water Commission, Canberra. http://archive.nwc.gov.au/_data/assets/pdf_ file/0019/10378/52_framework3.pdf. Accessed 10 May 2014

Gillig D, McCarl B, Jones L et al (2004) Economic efficiency and cost implications of habitat conservation: an example in the context of the Edwards Aquifer region. Water Resour Res. doi:10.1029/2003WR002749 
Gisser M (1983) Groundwater: focusing on the real issue. J Polit Econ 91:1001-1027

Gisser M, Sanchez D (1980) Competition versus optimal control in groundwater pumping. Water Resour Res 16:638-642

Goesch T, Hone S, Gooday P (2007) Groundwater management: issues affecting the efficient allocation of groundwater. Aust Commod 14:200-211

Griffin R (1998) The application of water market doctrines in Texas. In: Easter K, Rosengrant M, Dinar A (eds) Markets for water. Potential and performance. Kluwer, Boston, pp 51-64

Hanak E (2003) Who should be allowed to sell water in California? Third-party issues and the water market. Public Policy Institute of California, San Francisco

Hanak E (2005) Stopping the drain: third-party responses to California's water market. Contemp Econ Policy 23:59-77

Hanak E, Stryjewski E (2012) California's water markets, by the numbers: update 2012. Public Policy Institute of California, San Francisco

Hansen J (2012) The economics of optimal groundwater management in Southwestern USA. Hydrogeol J 20:865-877

Jacobs N (2006) California: groundwater management, conjunctive use and water banking. West Water Law Policy Rep 10:122-125

Juchems E (2013) Predicting groundwater trading participation in the Upper Republican River Natural Resource District. Masters Dissertation, University of Nebraska-Lincoln

Katic P, Grafton R (2012) Economic and spatial modelling of groundwater extraction. Hydrogeol J 20:831-834

Kenny J, Barber N, Hutson S et al (2009) Estimated use of water in the United States in 2005. U.S. Geological Survey Circular, Reston, 1344

Loch A, Wheeler S, Bjornlund $\mathrm{H}$ et al (2013) The role of water markets in climate change adaptation. National Climate Change Adaptation Research Facility, Gold Coast

Megdal S (2012) Arizona groundwater management. The water report. http://www.cwi.colostate. edu/southplatte/files/TWR_AZGroundWaterManagement.pdf. Accessed 10 May 2014

Meinzen-Dick R (1998) Groundwater markets in Pakistan: institutional development and productivity impacts. In: Easter K, Rosengrant M, Dinar A (eds) Markets for water-potential and performance. Kluwer, Boston, pp p207-p222

Moreaux M, Reynaud A (2004) Optimal joint management of a coastal aquifer and a substitute resource. Water Resour Res 40:W06S18. doi:10.1029/2003WR002166

NWC (2008) National water commission groundwater position statement. http://www.nwc.gov. au/_data/assets/pdf_file/0009/9729/Groundwater-position_statement.pdf. Accessed 26 Apr 2013

NWC (2010) The impact of water trading in the southern Murray Darling basin: an economic, social and environmental assessment. NWC, Canberra

NWC (2011) Strengthening Australia's water markets. NWC, Canberra

NWC (2012) Groundwater essentials. NWC, Canberra

NWC (2013) Australian water markets: trends and drivers 2007-08 to 2011-12. NWC, Canberra

Palazzo A, Brozović N (2014) The role of groundwater trading in spatial water management. Agric Water Manage. http://dx.doi.org/10.1016/j.agwat.2014.03.004

Richardson S, Evans R, Harrington G (2011) Connecting science and engagement: setting groundwater extraction limits using a stakeholder led decision-making process. In: Grafton Q, Connell D (eds) Basin futures: water reform in the Murray-Darling basin. Australia National University Press, Canberra

RRB (Republican River Basin) (2013) Sustainability steps - previous and planned actions in the republican basin to preserve water. Available at: http://www.urnrd.org/. Accessed 10 May 2014

Shah T (1993) Groundwater markets and irrigation development. Political economy and practical policy. Oxford University Press, Bombay

Shah T (2009) Taming the anarchy: groundwater governance in South Asia. Resources for the Future, Washington, DC 
Sitarz D (1993) AGENDA 21: the earth summit strategy to save our planet. Earth Press, Boulder Skurray J, Pannell D (2010) Potential approaches to the management of third-party impacts from groundwater transfers. Hydrogeol J 20:879-891

Skurray J, Pandit R, Pannell D (2013) Institutional impediments to groundwater trading: the case of the Gnangara groundwater system of Western Australia. J Environ Plan Manag $56: 1046-1072$

van der Gun J (2012) Groundwater and global change: trends, opportunities and challenges. UNESCO, Paris

Wang J, Huang J, Blanke A et al (2007) The development, challenges and management of groundwater in rural China. In: Giordano M, Giordano M, Vilholth K (eds) The agricultural groundwater revolution: opportunities and threats to development. CABI, Wallingford/ Cambridge, MA

Wentworth Group of Concerned Scientists (2012) Statement on the 2011 Draft Murray-Darling Basin Plan. http://wentworthgroup.org/wp-content/uploads/2013/10/Statement-on-the-2011Draft-Basin-Plan.pdf. Accessed 10 May 2014

Wheeler S, Loch A, Zuo A, Bjornlund H (2014) Reviewing the adoption and impact of water markets in the Murray-Darling Basin, Australia. J Hydrol 518:28-41

Young M (2014) Designing water entitlement regimes for an ever-changing and ever-varying future. Agric Water Manag. http://dx.doi.org/10.1016/j.agwat.2013.12.002

Zekri S, Al-Marshudi A (2008) A millenarian water rights system and water markets in Oman. Water Int 33:350-360

Zhang L, Wang J, Huang J et al (2008) Development of groundwater markets in China: a glimpse into progress to date. World Dev 36:706-726 